\title{
Recent Achievements and Challenges in Prolonging the Serum Half-Lives of Therapeutic IgG Antibodies Through Fc Engineering
}

\author{
Sanghwan $\mathrm{Ko}^{1,2} \cdot$ Migyeong Jo ${ }^{1,3} \cdot$ Sang Taek Jung ${ }^{1,2,3,4,5}$ \\ Accepted: 7 February 2021 / Published online: 19 February 2021 \\ (c) The Author(s), under exclusive licence to Springer Nature Switzerland AG part of Springer Nature 2021
}

\begin{abstract}
Association of FcRn molecules to the Fc region of IgG in acidified endosomes and subsequent dissociation of the interaction in neutral $\mathrm{pH}$ serum enables IgG molecules to be recycled for prolonged serum persistence after internalization by endothelial cells, rather than being degraded in the serum and in the lysosomes inside the cells. Exploiting this intracellular trafficking and recycling mechanism, many researchers have engineered the Fc region to further extend the serum half-lives of therapeutic antibodies by optimizing the $\mathrm{pH}$-dependent $\mathrm{IgG} \mathrm{Fc}-\mathrm{FcRn}$ interaction, and have generated various $\mathrm{Fc}$ variants exhibiting significantly improved circulating half-lives of therapeutic IgG antibodies. In order to estimate pharmacokinetic profiles of IgG Fc variants in human serum, not only a variety of in vitro techniques to determine the equilibrium binding constants and instantaneous rate constants for $\mathrm{pH}$-dependent FcRn binding, but also diverse in vivo animal models including wild-type mouse, human FcRn transgenic mouse ( $\mathrm{Tg} 32$ and $\mathrm{Tg} 276$ ), humanized mouse (Scarlet), or cynomolgus monkey have been harnessed. Currently, multiple IgG Fc variants that have been validated for their prolonged therapeutic potency in preclinical models have been successfully entered into human clinical trials for cancer, infectious diseases, and autoimmune diseases.
\end{abstract}

\section{$1 \mathrm{pH}-$ Dependent Interaction of IgG and Neonatal Fc Receptor}

Among therapeutic antibodies containing engineered Fc variants for improved serum half-life, Ultomiris ${ }^{\circledR}$ (ravulizumab-cwvz) was first approved by the US FDA in 2018, and was in the spotlight because it has fourfold longer frequency of administration compared with Soliris ${ }^{\circledR}$ (eculizumab) targeting the same indication. A main reason leading to this excellent serum persistence of the drug is that the engineered $\mathrm{Fc}$ region of Ultomiris ${ }^{\circledR}$ recirculates more

Sang Taek Jung

sjung@korea.ac.kr

1 Department of Biomedical Sciences, Korea University College of Medicine, Seoul, Republic of Korea

2 Institute of Human Genetics, Korea University College of Medicine, Seoul, Republic of Korea

3 BK21 Graduate Program, Department of Biomedical Sciences, Korea University College of Medicine, Seoul, Republic of Korea

4 Department of Biomedical Sciences, Graduate School, Korea University, Seoul, Republic of Korea

5 Biomedical Research Center, Korea University Anam Hospital, Seoul, Republic of Korea

\section{Key Points}

The $\mathrm{pH}$-dependent interaction between the $\mathrm{Fc}$ region of IgG and FcRn is crucial for enhanced circulating half-life of an IgG antibody, and various Fc variants with enhanced $\mathrm{pH}$-selective binding profile have been developed through rational design or a combinatorial approach.

To characterize $\operatorname{IgG}$ antibody Fc variants, equilibrium dissociation constants and instantaneous rate constant for Fc-FcRn interaction at both endosome and serum $\mathrm{pH}$ conditions have been analyzed, and a cell-based assay system that mimics serum recycling of IgG has been developed.

For the prediction of improved serum persistence of $\operatorname{IgG}$ antibody $\mathrm{Fc}$ variants in humans, various in vivo animal models such as transgenic mice (Tg32/Tg276/scarlet) and cynomolgus monkeys have been utilized.

Recently, Fc-engineered therapeutic antibodies with prolonged circulating half-lives have been validated in human clinical trials for various indications. 
effectively via interaction with human neonatal $\mathrm{Fc}$ receptor $(\mathrm{hFcRn})$. The importance of the IgG-FcRn interaction has been demonstrated in a mouse study, where the circulating half-life of mouse IgG1 antibody is only 1.4 days in FcRndeficient mice $\left(\mathrm{mFcRn}^{-/}\right)$, compared with a half-life of 9 days in $\mathrm{mFcRn}^{-/+}$and $\mathrm{mFcRn}{ }^{+/+}$mice [1]. The recycling of $\mathrm{IgG}$ antibodies depends on the $\mathrm{pH}$-dependent interaction with FcRn in particular. FcRn in the acidified endosomes binds with IgG antibodies that have been transported into the endosome by the pinocytosis mechanism, thereby preventing degradation of the antibodies via the lysosomal pathway. Because these antibodies show non-detectable binding affinity with $\mathrm{FcRn}$ at the neutral $\mathrm{pH}$ of the serum, they readily dissociate in the blood for re-circulation (Fig. 1a) [2]. These biological properties of antibodies are closely related to not only serum recycling but also transcytosis, a mechanism of antibodies or albumin for passing through the cells [2-4]. The $\mathrm{CH} 2-\mathrm{CH} 3$ interface region of the IgG $\mathrm{Fc}$ region binds to $\mathrm{FcRn}$, which is a heterodimer consisting of an $\alpha$-chain and a $\beta-2$ microglobulin $\left(\beta_{2} \mathrm{~m}\right)$ (Fig. 1b) [5]. Although it is well known that the $\alpha$-chain of FcRn interacts directly with IgG Fc, $\beta_{2} \mathrm{~m}$ also affects the structural stability and function of FcRn via a non-covalent assembly with the $\alpha$-chain $[4,6]$, explaining that $\beta_{2}$ m-deficient mice show abnormally low serum levels of $\operatorname{IgG}[6-8]$. To facilitate $\mathrm{pH}$ dependent binding with strong binding at slightly acidic $\mathrm{pH}$ values $(\mathrm{pH} 5.5-6.5)$ and rapid dissociation at the physiological pH (pH 7.0-7.5), Ile253, Ser254, His310, His433,
His435, and Tyr436 amino acid residues in the $\mathrm{CH} 2-\mathrm{CH} 3$ interface region of $\mathrm{Fc}$ are known to be extremely important for binding with FcRn (Fig. 1b) [5, 9-11]. In particular, the His residues show pKa values in the range of 6.0-6.5 [12] and the imidazole side chains of the His residues undergo protonation to form a salt bridge with acidic residues on FcRn (Glu115 and Asp130), resulting in non-covalent bonding between $\mathrm{Fc}$ and FcRn that can act as a sensitive $\mathrm{pH}-$ dependent switch $[2,13]$. In addition, the $\mathrm{CH} 2-\mathrm{CH} 3$ interface in the $\mathrm{Fc}$ region of human IgG1 contains a highly conserved Met252 (on the $\mathrm{CH} 2$ domain) and Met428 (on the $\mathrm{CH} 3$ domain) [14], and these Met residues form methionine sulfoxide (MetO) when oxidized, which significantly alters the structure of the $\mathrm{Fc}$ region and has been reported to impair Fc-FcRn interactions $[15,16]$. The effects of each Met residue on FcRn binding have been analyzed using sitedirected mutagenesis and Met252 oxidation was found to have a greater negative effect on FcRn binding than Met428 oxidation [14, 17].

There are numerous strategies aimed at improving the serum half-lives of short-lived therapeutic proteins using the FcRn interaction-mediated recycling mechanism such as either direct fusion or indirect targeting of $\mathrm{pH}$-dependent FcRn binding molecules like Fc domain or albumin [10, 18-26]. Considering that Fc-engineered therapeutic antibody was first approved by the US FDA [27], and the emerging significance of serum persistence of $\mathrm{IgG}$ antibodies for viral diseases [28, 29] or cancer [30] therapy, we focused

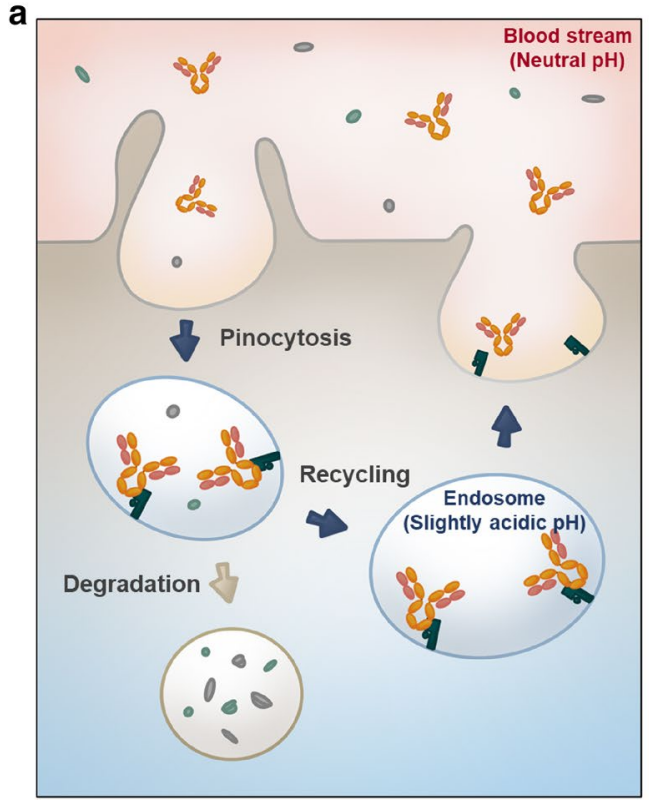

Fig. 1 Interaction between $\mathrm{IgG} \mathrm{Fc}$ and the neonatal $\mathrm{Fc}$ receptor. a Recycling of serum IgG by $\mathrm{pH}$-dependent binding with FcRn. b Complex structure of human FcRn and human IgG Fc variant (M252Y/S254T/T256E) (PDB: 4NOU). The key amino acid residues

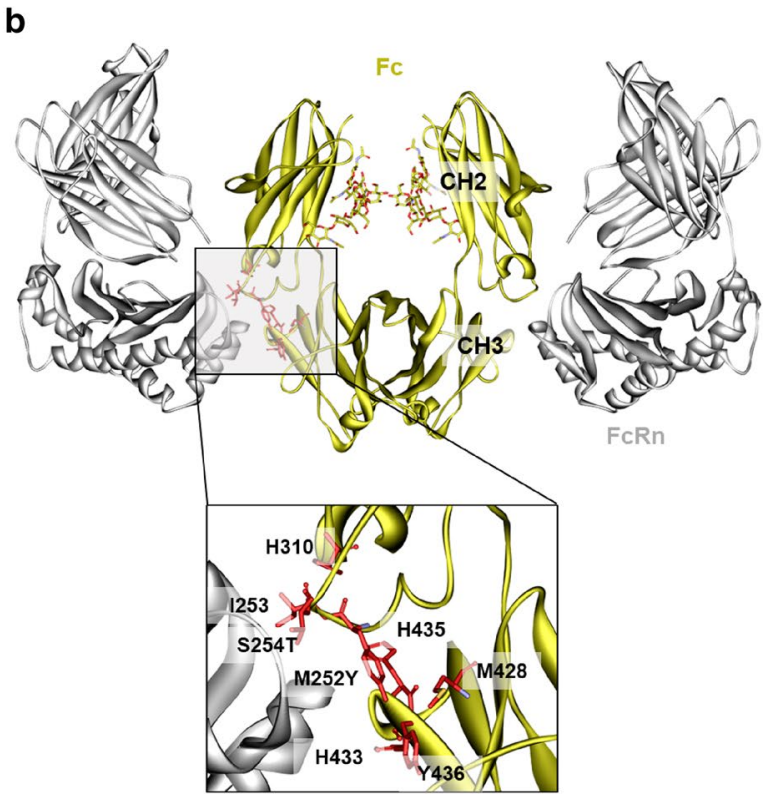

of human $\mathrm{Fc}$ region that highly contribute to the $\mathrm{pH}$-dependent interaction with human FcRn were annotated in the crystal structure. The numbers of amino acid were denoted based on the Kabat EU numbering system 
on $\mathrm{Fc}$ engineering studies to enhance circulating half-lives of IgG antibodies via modulating the FcRn binding. In this review, we present $\mathrm{Fc}$ variants engineered to extend the serum half-lives of IgG antibodies by amino acid modification for superior $\mathrm{pH}$-dependent interaction with $\mathrm{FcRn}$, the analytical methods to assess the pharmacokinetic profiles of the IgG Fc variants using in vitro and in vivo models including a variety of transgenic mouse $(\mathrm{Tg} 32, \mathrm{Tg} 276$, and scarlet mouse) models and a cynomolgus monkey model, and the latest human clinical trials to evaluate the utility of the half-life-extending Fc variants applied to therapeutic IgG antibodies in a clinical area for various indications such as immune disorders, viral diseases, or cancer.

\section{Fc Variants with Improved FcRn-IgG Interaction for Half-Life Extension}

Understanding the structure and characteristics of FcRn-IgG interactions has provided a basis for engineering works to improve the serum half-lives of $\operatorname{IgG}$ antibodies [11, 31, 32]. Zalevsky et al. used a combination of high-throughput protein screening and rational design methods to discover the M428L/N434S (LS) variant, which has an 11-fold higher $\mathrm{hFcRn}$ binding affinity at $\mathrm{pH} 6.0$ compared with the wildtype (Table 1) [30]. The authors introduced the LS variant into two model antibodies (bevacizumab and cetuximab) and confirmed 4.3-fold and 4.8-fold prolonged serum half-lives in an $\mathrm{hFcRn}$ transgenic ( $\mathrm{Tg}$ ) mouse model and 3.2-fold and 3.1-fold longer serum half-lives in a cynomolgus monkey model, respectively. Furthermore, they performed a xenograft study using an $\mathrm{hFcRn} / \mathrm{Rag} 1^{-1-}$ mouse model to investigate whether the enhanced pharmacokinetic properties also improved efficacy and found that anticancer antibodies with the half-life-extending Fc variant remarkably increased inhibition of tumor cell growth. In addition to improving the serum half-lives of IgG antibodies, the LS variant showed improved $\operatorname{IgG}$ transfer efficiency from blood to mucosa by $\mathrm{hFcRn}$, which led to higher concentrations in the mucosa and improved prophylactic protection against primate SHIV infection through the mucosa $[28,29,33]$. Borghi et al. utilized the LS mutant to understand maternal transfer of the IgG antibody to the fetus and found that only interaction with $\mathrm{FcRn}$ determines the transfer of maternal antibodies [34]. This differs from a previous report by Jennewein et al., in which only maternal antibodies with a specific glycan were selectively transferred to the fetus by an FcrRIIIamediated mechanism [35].

Dall'Acqua et al. [36] used phage display to discover the M252Y/S254T/T256E (YTE) variant, which showed 10 -fold higher binding affinity with $\mathrm{hFcRn}$ (Table 1 ). The MEDI-524 with the YTE variant, an antibody targeting respiratory syncytial virus (RSV), showed an almost 3.7-fold longer serum half-life in a cynomolgus monkey model [37]. Oganesyan et al. reported the crystal structure for the complex of the YTE variant and $\mathrm{hFcRn}$, offering a molecular understanding of the interactions between human IgG antibodies and hFcRn [38].

Yeung et al. used phage display to discover N434A and N434W variants (Table 1) [39]. In that paper, the authors analyzed the correlation between the in vitro FcRn binding affinity and in vivo pharmacokinetics using the $\mathrm{N} 434 \mathrm{~W}$ variant, which showed improved binding affinity at both $\mathrm{pH} 6.0$ and $\mathrm{pH} 7.4$, and the N434A variant, which showed improved binding affinity at $\mathrm{pH} 6.0$ but similar binding affinity to wildtype at $\mathrm{pH}$ 7.4. In a cynomolgus monkey model, the N434A variant showed a 2.3-fold longer half-life but the half-life of the N434W variant was not improved. These findings reassert the importance of $\mathrm{pH}$-dependent FcRn binding by demonstrating that significantly increased binding affinity at $\mathrm{pH} 7.4$ does not increase the half-life of antibodies, even with a greatly improved binding affinity at $\mathrm{pH}$ 6.0.

More recently, multiple Fc variants identified by various rational or combinatorial approaches have been reported (Table 1) [40]. Mackness et al. constructed a library with saturation point mutations at the amino acids critical for interactions with FcRn and used biolayer interferometry (BLI) to screen candidate human Fc variants. Next, the authors additionally analyzed the binding affinity for $\mathrm{hFcRn}$ and identified T256D/T307Q (DQ), T256D/T307W (DW), and M252Y/T256D (YD) exhibiting 2.1-fold, 2.1fold, and 2.4-fold improved serum half-lives compared with wild-type Fc in a cynomolgus monkey model, respectively. Booth et al. discovered T307Q/Q311V/A378V and T256D/ H286D/T307R/Q311V/A378V variants using a structurebased design, and the antibody Fc variants showed 3.1-fold and 3.9-fold longer half-lives, respectively, compared with the counterpart antibody with wild-type Fc in a cynomolgus monkey model (Table 1) [41]. Lee et al. discovered L309D/ Q311H/N434S (DHS) by displaying full-length IgG on the bacterial inner membrane [42] and verified a 4.1-fold longer serum half-life in a humanized mouse model [Scarlett $\left.\left(\mathrm{hFcRn}^{+/-} \mathrm{h} \beta 2 \mathrm{~m}^{+/-} \mathrm{hFc} \gamma \mathrm{R}^{+/-} \mathrm{hIgG1}^{+/-}, \mathrm{\kappa}^{+/-}\right)\right]($Table 1 , Fig. 2c) [43]. In the study, the DHS variant exhibiting a lower binding affinity at $\mathrm{pH} 7.4$ showed an improved serum half-life compared with the LS and YTE variants, which maintained a certain level of binding affinity with FcRn at pH 7.4.

In this section, we describe various engineered Fc variants exerting enhanced $\mathrm{pH}$-dependent FcRn binding and prolonging circulating half-lives of $\mathrm{IgG}$ antibodies. LS and YTE variants have been adopted for therapeutic IgG antibodies, and their therapeutic utility resulting from enhanced pharmacokinetic profiles have been validated in human clinical trials. In addition, studies using N434A, N434W, and several recently reported $\mathrm{Fc}$ variants revealed that not only 
Table 1 List of engineered Fc variants with enhanced binding to human FcRn

\begin{tabular}{|c|c|c|c|c|c|c|}
\hline \multirow[t]{2}{*}{ Mutations $^{\mathrm{a}}$} & \multirow[t]{2}{*}{$\begin{array}{l}\text { Model antibody } \\
\text { (target antigen) }\end{array}$} & \multirow{2}{*}{$\begin{array}{l}\text { Fold increase of } \\
\text { affinity at pH } 6.0 \\
\text { (vs wild-type Fc) }\end{array}$} & \multirow[t]{2}{*}{ Affinity at $\mathrm{pH} 7.4$} & \multicolumn{2}{|c|}{$\begin{array}{l}\text { Fold increase of half-life } \\
\text { (vs wild type Fc) }\end{array}$} & \multirow[t]{2}{*}{ References } \\
\hline & & & & $\begin{array}{l}\text { Tg mouse } \\
\text { (mouse strain) }\end{array}$ & $\begin{array}{l}\text { Cynomolgus } \\
\text { monkey }\end{array}$ & \\
\hline \multirow[t]{2}{*}{ M428L/N434S } & $\begin{array}{l}\text { Bevacizumab } \\
\text { (VEGF) }\end{array}$ & $\sim 11.28$ & Low & $\begin{array}{l}\sim 4.3 \\
\text { (Tg } 276 \text { hemizygote) }\end{array}$ & $\sim 3.2$ & {$[30]$} \\
\hline & $\begin{array}{l}\text { Cetuximab } \\
\text { (EGFR) }\end{array}$ & & & $\begin{array}{l}\sim 4.8 \\
\text { (Tg } 276 \text { hemizygote) }\end{array}$ & $\sim 3.1$ & \\
\hline M252Y/S254T/T256E & $\begin{array}{l}\text { MEDI-524 } \\
\text { (RSV) }\end{array}$ & $\sim 11$ & Low & & $\sim 3.7$ & {$[36,37]$} \\
\hline N434A & Anti-hBSR & $\sim 4$ & Low & & $\sim 2.3$ & [39] \\
\hline N434W & (hBSR) & $\sim 80$ & High & & $\sim 1.5$ & \\
\hline T256D/T307Q & $\begin{array}{l}\text { mAb2 } \\
\text { (Unknown) }\end{array}$ & $\sim 10$ & Low & $\begin{array}{l}\sim 2.1 \\
\text { (Tg } 32 \text { homozygote) }\end{array}$ & $\sim 2.1$ & {$[40]$} \\
\hline $\mathrm{T} 256 \mathrm{D} / \mathrm{T} 307 \mathrm{~W}$ & & $\sim 14$ & Low & $\begin{array}{l}\sim 1.7 \\
\text { (Tg } 32 \text { homozygote) }\end{array}$ & $\sim 2.1$ & \\
\hline M252Y/T256D & & $\sim 25$ & Low & $\begin{array}{l}\sim 1.5 \\
\operatorname{Tg} 32 \text { homozygote) }\end{array}$ & $\sim 2.4$ & \\
\hline T307Q/Q311V/A378V & $\begin{array}{l}\text { Motavizumab } \\
\text { (RSV) }\end{array}$ & $\sim 12.4$ & Low & $\begin{array}{l}\sim 10 \\
\text { (Tg } 276 \text { homozygote) }\end{array}$ & $\sim 3.1$ & {$[41]$} \\
\hline $\begin{array}{l}\text { T256D/H286D/T307R/ } \\
\text { Q311V/A378V }\end{array}$ & & $\sim 12.4$ & Low & $\begin{array}{l}\sim 9.4 \\
\text { (Tg } 276 \text { homozygote) }\end{array}$ & $\sim 3.9$ & \\
\hline L309D/Q311H/N434S & $\begin{array}{l}\text { Trastuzumab } \\
\text { (Her2) }\end{array}$ & $\sim 4.1$ & Very low & $\begin{array}{l}\sim 5.8 \\
\text { (Humanized mouse }^{\mathrm{b}} \text { ) }\end{array}$ & & {$[43]$} \\
\hline
\end{tabular}

The data in the table represent the results reported in the literature. It should be noted that the pharmacokinetic profiles are highly variable depending on antigen type and animal model

${ }^{a}$ The amino acid residue numbers of the mutations are represented based on the Kabat EU numbering system

${ }^{\mathrm{b}} \mathrm{Scarlett}\left(\mathrm{hFcRn}{ }^{\mathrm{KI}} \mathrm{h} \beta 2 \mathrm{~m}^{\mathrm{KI}} \mathrm{hFc} \gamma \mathrm{R}^{\mathrm{KI}} \mathrm{hIgG1}, \kappa^{\mathrm{KI}}\right)$ mouse model

$E G F R$ epidermal growth factor, $h B S R$ human B-cell surface receptor, $R S V$ respiratory syncytial virus, $V E G F$ vascular endothelial growth factor

enhancing FcRn binding affinity at slightly acidic $\mathrm{pH}$ but also reducing its affinity at neutral $\mathrm{pH}$ is essential to determine whether serum half-life is prolonged or not.

\section{In Vitro/in Vivo Models to Predict and Analyze the Serum Half-Life of IgG Fc Variants}

Many researchers have isolated $\mathrm{Fc}$ variants using library screening methods based on a display system or site-directed mutagenesis studies on amino acid residues that have been reported to be critical for the Fc-FcRn interaction. In addition, various methods have been developed to predict the pharmacokinetic profiles of the $\mathrm{IgG}$ antibody containing the identified $\mathrm{Fc}$ variants. One such method for predicting the serum half-life in vitro is to measure the quantitative binding affinity with $\mathrm{FcRn}$ both at $\mathrm{pH} 6.0$ and $\mathrm{pH}$ 7.4. However, because one hIgG homodimer binds with two hFcRn molecules, the quantitative rate constant and equilibrium dissociation constant can differ depending on the measurement method. To solve this problem, Abdiche et al. reported a method to more precisely quantify the FcRn-Fc binding affinity using a surface plasmon resonance (SPR) biosensor [44]. Souders et al. reported a method of screening for candidate Fc variants enabling an improved serum half-life of IgG. In the work, they used BLI to measure the instantaneous binding rate, rather than the equilibrium dissociation constant, at pH 6.0 and $\mathrm{pH} 7.4$ [45]. In addition to methods that quantitatively measure the binding affinity, there are methods that use cells to screen Fc variants expected to show a longer half-life. Grevys et al. developed a cell-based assay that mimics antibody recycling in the body and demonstrated that the results of using the assay for previously reported $\mathrm{Fc}$ variants were in strong agreement with a previous study [46].

To develop drugs based on the $\mathrm{Fc}$ variants verified in various in vitro studies, the pharmaceutical industry has been using the cynomolgus monkey model, a primate with 97\% sequence identity with $\mathrm{hFcRn}$ and similar expression levels in tissue $[47,48]$. The cynomolgus monkey model has been commonly used in assessments of antibody pharmacokinetics because it shares 90-93\% genetic homology with humans and has a similar genetic background. Moreover, 
a

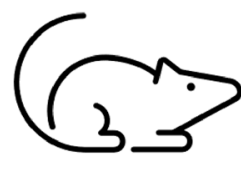

$\operatorname{Tg} 32$
$\mathrm{mFcRn}^{-/}, \mathrm{hFcRn}^{+/+}$or hFcRn ${ }^{+/-}$

Deletion of Fcgrt

FCGRT genomic DNA

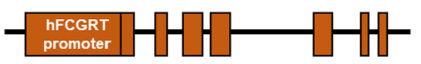

b

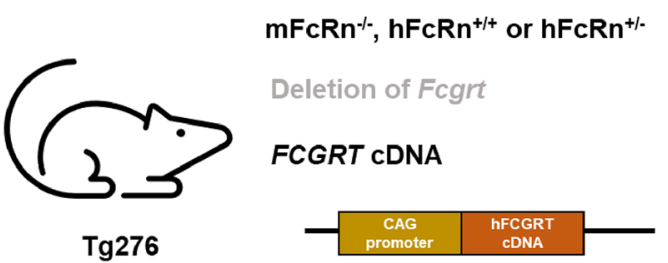

C

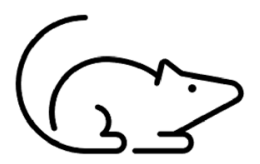

Scarlett
$\mathrm{mFCRn}^{* /}, \mathrm{hFCRn}^{+/}, \mathrm{h} \beta 2 \mathrm{~m}^{+/}, \mathrm{hFcyR}^{+/}, \mathrm{hlg}^{+/}$, and $\mathrm{K}^{+/}$

Deletion of multiple gene (Fcgrt, B2m, Fcgr1, Fcgr2b, Fcgr4, Fcgr3, S $\mu$, and Igk)

FCGRT

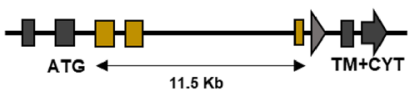

$B 2 M$
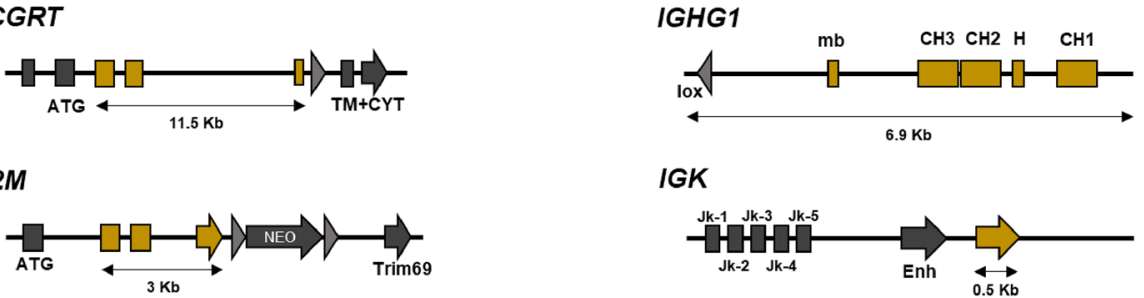

IGK

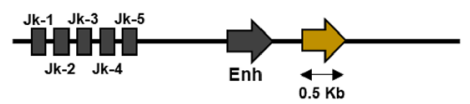

FCGR2B, FCGR3B, FCGR2C, FCGR3A, FCGR2A

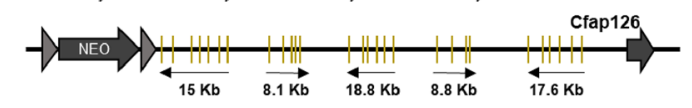

FCGR1A

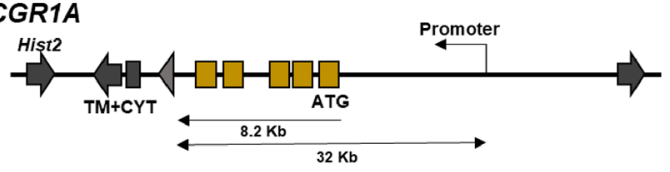

Fig. 2 In vivo mouse models that have been used for pharmacokinetic profile analysis of $\mathrm{Fc}$-engineered $\mathrm{IgG}$ antibodies. a-c Schematic representations of gene structures for mouse models: $\operatorname{Tg} 32$ (a), $\operatorname{Tg} 276$ (b), and Scarlett (c). B2M human $\beta-2$ microglobulin gene, FCGR1A human $\mathrm{Fc} \gamma$ receptor I gene, FCGR2A human Fc $\gamma$ receptor IIa gene, $F C G R 2 B$ human $\mathrm{Fc} \gamma$ receptor IIb gene, $F C G R 2 C$ human $\mathrm{Fc} \gamma$ receptor IIc gene, FCGR3A human $\mathrm{Fc} \gamma$ receptor IIIa gene, FCGR3B human

several studies have reported allometric scaling when analyzing the correlations between antibody pharmacokinetic profiles in cynomolgus monkey models and in humans [49-51]. However, because cynomolgus monkey models are too expensive to be used as a screening tool for Fc variants, the half-lives have been assessed using mouse models, which allow researchers to predict the pharmacokinetics in humans while being relatively inexpensive. Caution is required when using a normal mouse model to analyze the pharmacokinetics of antibody Fc variants, since human IgG shows a stronger binding affinity for $\mathrm{mFcRn}$ than for $\mathrm{hFcRn}$ and the Fc variants show different binding characteristics between hFcRn and mFcRn [52]. Most studies use the hFcRn Tg mouse model provided by the Jackson Laboratory to assess the improved serum half-lives of Fc-engineered therapeutic antibodies [53]. This model was created by disrupting the
Fc $\gamma$ receptor IIIb gene, FCGRT human neonatal Fc receptor gene, $I G H G 1$ human immunoglobulin heavy constant gamma 1 gene, IGK human immunoglobulin kappa gene, $B 2 m$ mouse $\beta-2$ microglobulin gene, Fcgrl mouse Fc $\gamma$ receptor I gene, Fcgr2b mouse Fc $\gamma$ receptor IIb gene, Fcgr3 mouse Fc $\gamma$ receptor III gene, Fcgr4 mouse Fc $\gamma$ receptor IV gene, Fcgrt mouse neonatal Fc receptor gene, Igk mouse immunoglobulin kappa gene, $S \mu \mathrm{S}$ region of heavy chain gene

Fcgrt (mFcRn) gene and inserting the $F C G R T(\mathrm{hFcRn})$ gene in C57BL/6J(B6) mice (Fig. 2a and b). This model can be divided into $\mathrm{Tg} 32$ and $\mathrm{Tg} 276$ lines depending on the type of FCGRT gene, where Tg32 contains human FCGRT genomic DNA and Tg276 contains human FCGRT cDNA [53, 54]. Generally, the $\operatorname{Tg} 276$ mouse model generates lower serum half-life of an IgG antibody and exhibits subtle differences among the serum half-lives among IgG antibody Fc variants more sensitively compared with the $\mathrm{Tg} 32$ mouse model [53, 55]. On the other hand, the $\operatorname{Tg} 32$ mouse model has similar tissue distribution of $\mathrm{hFcRn}$ to that of humans in contrast to the Tg276 mouse model, of which the hFcRn is expressed at high levels in all tissues [48]. In addition, the correlation of serum half-lives of $\mathrm{IgG}$ antibodies between $\mathrm{Tg} 32$ mice and cynomolgus monkeys has been validated, and the mouse model has been used to predict pharmacokinetic profiles of 
therapeutic antibodies in humans in various studies [56]. Based on the results reported so far, the $\operatorname{Tg} 32$ mouse model is preferred over the $\operatorname{Tg} 276$ mouse model for predicting the serum half-lives of IgG antibodies in humans.

Recently, for a pharmacokinetic profile analysis, Lee et al. employed Scarlett mice $\left(\mathrm{hFcRn}^{+/-} \mathrm{h} \beta 2 \mathrm{~m}^{+/-} \mathrm{hFc} \gamma \mathrm{R}^{+/-} \mathrm{hIgG1}^{+/-}, \mathrm{\kappa}^{+/-}\right.$mice), which added hIgG1 heavy chains and human kappa light chains in a Marlene mice model $\left(\mathrm{hFcRn}^{+/-} \mathrm{h} \beta 2 \mathrm{~m}^{+/-} \mathrm{hFc} \gamma \mathrm{R}^{+/-}\right.$mice) possessing human FcyR genes (FCGR1A, FCGR2A, FCGR2B, FCGR2C, FCGR3A, and FCGR3B), FCGRT, and $B 2 M$ (human $\beta 2 \mathrm{~m}$ gene) (Fig. 2c). The authors used the Scarlett mouse model to assess the half-lives of previously developed YTE and LS variants and their own DHS Fc variant. The DHS Fc variant showed a 1.5-fold longer half-life compared with previously reported Fc variants (YTE and LS) that are currently undergoing clinical trials for multiple antibodies [43].

\section{Clinical Applications}

\subsection{Immunological Disorders}

For Fc variants that have been proven to prolong the circulating half-life of the IgG antibody, several clinical studies are being conducted for various antigen-specific antibodies (Table 2). Of these, the most commonly used Fc variant is Xencor's LS variant (M428L/N434S), and as of September 20, 2020, there are eight antibodies using this platform that are in clinical trials. Ultomiris ${ }^{\circledR}$ (Ravulizumab-cwvz; administered at 8-week intervals), which was developed by Alexion, is an antibody targeting complement component 5 (C5). This antibody was approved by the US FDA in December 2018 for a phase III clinical trial [27] after demonstration of its safety and efficacy compared with eculizumab (administered at 2-week intervals), which is used to treat paroxysmal nocturnal hemoglobinuria (PNH). MEDI5117 is an example of a monoclonal antibody developed from a half-life-extended antibody using the YTE platform [57], and was developed by WuXi-Medimmune (joint venture of Medimmune and Wuxi Apptec) to treat rheumatoid arthritis (RA). This Fc-engineered therapeutic antibody was developed with a target antigen of interleukin-6 (IL-6), which is a key mediator causing pain and inflammation in various pathologic states [57], and is currently undergoing phase I clinical trials in the US and Europe.

\subsection{Cancer}

For anti-cancer therapy, three bispecific antibodies using Xtend $^{\mathrm{TM}}$ technology (XmAb20717: PD-1 × CTLA-4, XmAb23104: PD-1 $\times$ ICOS, and XmAb22841: CTLA-4 $\times$
LAG-3) are in phase I clinical trials targeting solid tumors. These are bispecific antibodies that can prevent tumor-reactive $\mathrm{T}$-cell downregulation and reactivate $\mathrm{T}$ cells, restoring the immune response in the tumor microenvironment (TME) by targeting appropriate combinations of programmed cell death protein-1 (PD-1), cytotoxic T-lymphocyte-associated antigen-4 (CTLA-4), inducible T-cell co-stimulator (ICOS), or lymphocyte activation gene-3 (LAG-3). In clinical applications, these antibodies are intended to not only selectively bind $\mathrm{T}$ cells that highly express the immune checkpoint targets, but also to reduce the need for combination therapy. Additionally, the serum half-lives were greatly improved by introducing Xtend ${ }^{\mathrm{TM}}$, which enables enhanced therapeutic effects and reduced frequency of administration of antibodies [58-60].

\subsection{Viral Infectious Diseases}

Clinical studies are being conducted on antibodies containing half-life extension $\mathrm{Fc}$ variants to treat viral diseases. In particular, VIR-7831 (GSK4182136), which was developed by Vir Biotechnology and GlaxoSmithKline (GSK), used $\mathrm{Xtend}^{\mathrm{TM}}$ as a therapeutic antibody against severe acute respiratory syndrome coronavirus-2 (SARS-CoV-2). The antibody has been confirmed to neutralize the SARS-CoV-2 live virus by strongly binding to its spike protein $\left(K_{\mathrm{D}}\right.$ value of S309-IgG1 and SARS-CoV-2 spike: $1.5 \times 10^{-11} \mathrm{M}$ ) [61] and is currently in a phase II/III clinical trial. Other antiviral antibodies being developed by Vir Biotechnology with Xtend $^{\text {TM }}$ include VIR-2482 and VIR-3434. VIR-2482 is an influenza A-neutralizing $\mathrm{mAb}$ that binds to the conserved region of hemagglutinin (HA) and neutralizes all major strains since the Spanish flu in 1918 (H1N1), which suggests the feasibility of using the antibody for a universal prophylactic vaccine, overcoming the limitations of current influenza vaccines, where the antibody response is dependent on individual seasonal antigens. In addition, because the serum half-life is increased, a single dose can last the entire influenza season of around 5-6 months. VIR-3434 is a monoclonal neutralizing antibody for chronic hepatitis B virus (HBV) infections. The company, Vir, claims that VIR-3434 prevents all ten HBV genotypes from entering hepatocytes and reduces the levels of virions and subviral particles in the blood. Also, they assert that the experimental results using a mouse model indicate that virions or subviral particles captured by VIR-3434 could stimulate maturation of dendritic cells (DCs) by an interaction between Fc domain of VIR-3434 and FcyRs on immature DCs, and ultimately it could have a vaccine-like property by generating HBV-specific T cells. Published preclinical and clinical data on VIR-3434 containing engineered Fc is eagerly awaited. Other antiviral antibodies include VRC01LS and elipovimab (GS-9722) for HIV, and nirsevimab (MEDI8897) 
Table 2 Clinical status of therapeutic antibodies with extended serum half-lives

\begin{tabular}{|c|c|c|c|c|}
\hline Name & Target & Format & Primary indication & Clinical phase* \\
\hline XmAb20717 & PD- $1 \times$ CTLA- 4 & Bispecific/Xtend & Oncology & $\begin{array}{l}\text { I } \\
\text { (NCT03517488) }\end{array}$ \\
\hline XmAb23104 & PD-1 $1 \times \mathrm{ICOS}$ & Bispecific/Xtend & Oncology & $\begin{array}{l}\text { I } \\
\text { (NCT03752398) }\end{array}$ \\
\hline $\mathrm{XmAb} 22841$ & CTLA-4 × LAG-3 & Bispecific/Xtend & Oncology & $\begin{array}{l}\text { I } \\
\text { (NCT03849469) }\end{array}$ \\
\hline VRC01LS & CD4-binding site on gp120 of HIV-1 & $\mathrm{mAb} / \mathrm{Xtend}$ & HIV & $\begin{array}{l}\text { I } \\
\text { (NCT02599896) }\end{array}$ \\
\hline $\begin{array}{l}\text { Elipovimab } \\
\text { (GS-9722) }\end{array}$ & V3 glycan motif on gp120 of the HIV & mAb/Cytotoxic/Xtend & HIV & I $[62,76,77]$ \\
\hline VIR-2482 & Influenza A HA & $\mathrm{mAb} / \mathrm{Xtend}$ & Influenza A & $\begin{array}{l}\mathrm{I} / \mathrm{II} \\
\text { (NCT04033406) }\end{array}$ \\
\hline VIR-3434 & Conserved region of $\mathrm{HBsAg}$ & $\mathrm{mAb} / \mathrm{Xtend}$ & Chronic HBV infection & $\begin{array}{l}\text { I } \\
\text { (NCT04423393) }\end{array}$ \\
\hline MEDI 5117 & IL-6 & $\mathrm{mAb} / \mathrm{YTE}$ & RA & $\begin{array}{l}\text { I } \\
\text { (NCT01559103) }\end{array}$ \\
\hline VIR-7831 (GSK4182136) & SARS-CoV-2 & $\mathrm{mAb} / \mathrm{Xtend}$ & COVID-19 & $\begin{array}{l}\text { II/III } \\
\text { (NCT04545060) }\end{array}$ \\
\hline Nirsevimab (MEDI8897) & RSV F protein & $\mathrm{mAb} / \mathrm{YTE}$ & RSV infection & $\begin{array}{l}\text { III } \\
\text { (NCT03979313) }\end{array}$ \\
\hline Ravulizumab (Ultomiris $^{\circledR}$ ) & C5 & $\mathrm{mAb} / \mathrm{Xtend}$ & PNH, aHUS & $\begin{array}{l}\text { Approved } \\
\text { (NCT03056040) }\end{array}$ \\
\hline
\end{tabular}

aHUS atypical hemolytic uremic syndrome, $C T L A-4$ cytotoxic T-lymphocyte-associated antigen- $4, H A$ hemagglutinin, $H B V$ hepatitis $\mathrm{B}$ virus, $H I V$ human immunodeficiency virus, ICOS inducible T-cell co-stimulator, $L A G-3$ lymphocyte activation gene-3, $P D-1$ programmed cell death protein-1, $P N H$ paroxysmal nocturnal hemoglobinuria, $R A$ rheumatoid arthritis, $R S V$ respiratory syncytial virus

*ClinicalTrials.gov identifiers are included in parentheses. The identifier for elipovimab is not listed on the website

for RSV [62]. VRC01LS and elipovimab, which were developed by the NIH and Gilead Science, respectively, utilize Xtend $^{\mathrm{TM}}$ and are in human phase I clinical trials. VRC01LS shows an approximately fourfold longer serum half-life than the counterpart antibody with wild-type Fc (VRC01) and showed similar neutralizing activity in serum to VRC01 during 48 weeks of a phase I clinical trial [63, 64]. Elipovimab is derived from the HIV-neutralizing antibody PGT121 [65, $66]$ and consists of the Fab region, which is engineered to lower the immunogenicity and improve the stability at low $\mathrm{pH}$, and the $\mathrm{Fc}$ region, which is engineered for prolonged serum half-life using Xtend ${ }^{\mathrm{TM}}$ and for enhanced binding affinity to Fc $\gamma$ RIIIa (158Val/Phe) and Fc $\gamma$ RIIa (131His/ $\mathrm{Arg}$ ) by introducing $\mathrm{Fc} \gamma \mathrm{R}$ binding enhancing mutations $[30,67,68]$. Through these modifications, the antibody was designed to show not only HIV-neutralizing activity, but also enhanced effector functions such as antibody-dependent cell-mediated cytotoxicity (ADCC) by natural killer (NK) cells and antibody-dependent cellular phagocytosis (ADCP) by macrophages [62]. Nirsevimab, an mAb targeting RSV fusion (F) glycoprotein that mediates virus entry through fusion of the viral membrane with the host cell membrane [69], was developed in collaboration with AstraZeneca and Sanofi Pasteur using the YTE platform [70]. MEDI8897 containing the YTE variant is currently in a phase III clinical trial. In a phase Ib/IIa trial in healthy preterm infants (32-35 weeks), MEDI8897 showed a very long serum half-life $\left(t_{1 / 2}\right)$ of 62.5-72.9 days. The antibody reached the $90 \%$ effective concentration target level $\left(\mathrm{EC}_{90}\right)$ in $87 \%$ of the $50-\mathrm{mg}$ dose group and showed a more than fourfold higher RSV-neutralizing antibody level. Thus, the half-life-extended antiRSV-neutralizing antibody MEDI8897 was shown to offer protection from RSV for a typical 5-month season with a single intramuscular (IM) dose (50 mg) [71].

\section{Discussion}

Human IgG antibodies show much longer serum half-lives (around 3 weeks) compared with other therapeutic proteins due to recycling via interactions with $\mathrm{hFcRn}$. Because the feasibility of research on half-life-extending Fc variants and the clinical utility of using therapeutic antibodies with the developed $\mathrm{Fc}$ variant have been well demonstrated, many pharmaceutical companies and research institutes are making huge efforts to prolong the antibody half-lives by improving the $\mathrm{pH}$-dependent FcRn binding profiles [40, 41, 43]. 
Considering the very narrow range of $\mathrm{pH}$ difference between the endosome ( $\mathrm{pH} 5.5-6.0)$ and serum $(\mathrm{pH} ~ 7.4)$, it is extremely difficult to fine tune the Fc-FcRn interaction for very high $\mathrm{pH}$ selectivity, which enables generation of Fc variants for dramatically improved serum half-lives of therapeutic antibodies [39]. However, accumulated structural insights and directed evolution techniques equipped with various cutting-edge high throughput screening platforms have allowed isolation of $\mathrm{Fc}$ variants with enhanced pH-dependent FcRn binding capability. As research on various engineered $\mathrm{Fc}$ variants has been actively conducted, the requirements that $\mathrm{Fc}$ variants must satisfy for an improved half-life have been suggested. Borrok et al. proposed that the half-life of the $\mathrm{IgG}$ antibody does not increase or even decrease when the affinity with FcRn at the $\mathrm{pH}$ of the Fc variant (7.4) is above a certain level [72]. To verify this hypothesis and to determine the threshold level of the FcRn binding affinity at $\mathrm{pH} 7.4$, which is necessary for increasing the serum half-life of the $\mathrm{IgG}$ antibody, a variety of engineered $\mathrm{Fc}$ variants with various $\mathrm{pH}-$ dependent $\mathrm{FcRn}$ binding profiles should be discovered and the pharmacokinetic profiles of antibodies containing these $\mathrm{Fc}$ variants should be analyzed. Although the immunogenicity issue caused by the use of engineered $\mathrm{Fc}$ variants has not been reported for therapeutic antibodies that are approved or in human clinical trials, there are several experimental reports that some Fc variants could bind to rheumatoid factor [40, 43]. Therefore, thorough evaluation of potential immunogenicity for $\mathrm{IgG}$ antibodies containing Fc variants is necessary in the clinical development stage.

The major factor that determines whether or not the halflife is improved is the $\mathrm{pH}$-dependent binding between $\mathrm{Fc}$ and $\mathrm{FcRn}$, but there are other factors that affect the serum half-life of IgG, such as the isoelectric point (pI) of the antibody and self-interaction between antibodies, which should definitely be considered [73-75]. For this reason, to evaluate the half-life of an antibody introduced with an Fc variant, a pharmacokinetic analysis using in vivo models ( $\operatorname{Tg} 32$ mice, $\mathrm{Tg} 276$ mice, humanized mice, cynomolgus monkeys, etc.) is crucial, as well as simply analyzing the FcRn binding affinities and physicochemical properties of the Fc-engineered antibodies. Since these animal model studies are costly and time consuming, in vitro analysis methods that can predict the in vivo half-lives of $\mathrm{IgG} \mathrm{Fc}$ variants at reduced cost are in high demand, and seminal works related to this have been reported $[45,46]$. However, the in vitro analysis methods developed to date have limitations in that they cannot take into account transport phenomena during $\mathrm{IgG}$ antibody circulation in the blood vessels of the body and during ADME (absorption, distribution, metabolism, and excretion). Therefore, to predict more precisely the pharmacokinetic profile of a variety of $\mathrm{IgG} \mathrm{Fc}$ variants with reduced time and costs, it is absolutely necessary to develop in vitro analysis systems that consider the critical parameters related to $\operatorname{IgG}$ circulation in an in vivo environment.

\section{Conclusion}

Isolation of various engineered $\mathrm{Fc}$ variants with endosome $\mathrm{pH}$-selective $\mathrm{FcRn}$ binding capability and understanding of the parameters that affect the in vivo serum half-life will enable tailoring of the serum persistence of therapeutic antibodies. Therapeutic antibodies with improved half-lives not only lead to reduced patient inconvenience resulting from frequent injections, but also to enhanced therapeutic efficacy as an additional effect of improved serum persistence in the body [28-30, 33]. In addition, the developed Fc variants can be applied to develop monoclonal antibodies as prophylactic vaccines against novel infectious microorganisms such as SARS-CoV-2.

\section{Declarations}

Funding This work was supported by grants from the Bio and Medical Technology Development Program (2020M3E5E2037775) and the Basic Science Research Programs (2019R1F1A1059834, 2019R1A4A1029000, and 2020R1A6A3A01099189) through the National Research Foundation of Korea funded by the Ministry of Science and ICT and by the Ministry of Education, and by a Korea National Institute of Health fund (2020-ER5311-00).

Conflicts of interest The authors declare no conflicts of interest.

Ethics approval Not applicable.

Consent to participate Not applicable.

Consent for publication Not applicable.

Availability of data and materials Not applicable.

Code availability Not applicable.

Author contributions All authors reviewed and commented on the manuscript. All authors read and approved the final manuscript.

\section{References}

1. Roopenian DC, Christianson GJ, Sproule TJ, Brown AC, Akilesh $\mathrm{S}$, Jung N, et al. The MHC class I-like IgG receptor controls perinatal IgG transport, IgG homeostasis, and fate of IgG-Fc-coupled drugs. J Immunol. 2003;170(7):3528-33. https://doi.org/10.4049/ jimmunol.170.7.3528.

2. Raghavan M, Bonagura VR, Morrison SL, Bjorkman PJ. Analysis of the $\mathrm{pH}$ dependence of the neonatal $\mathrm{Fc}$ receptor/immunoglobulin $\mathrm{G}$ interaction using antibody and receptor variants. Biochemistry. 1995;34(45):14649-57. https://doi.org/10.1021/bi00045a005.

3. Roopenian DC, Akilesh S. FcRn: the neonatal Fc receptor comes of age. Nat Rev Immunol. 2007;7(9):715-25. https://doi. org/10.1038/nri2155. 
4. Pyzik M, Sand KMK, Hubbard JJ, Andersen JT, Sandlie I, Blumberg RS. The neonatal Fc receptor $(\mathrm{FcRn})$ : a misnomer? Front Immunol. 2019. https://doi.org/10.3389/fimmu.2019.01540.

5. Burmeister WP, Huber AH, Bjorkman PJ. Crystal structure of the complex of rat neonatal Fc receptor with Fc. Nature. 1994;372(6504):379-83. https://doi.org/10.1038/372379a0.

6. Praetor A, Hunziker W. beta(2)-Microglobulin is important for cell surface expression and $\mathrm{pH}$-dependent $\mathrm{IgG}$ binding of human FcRn. J Cell Sci. 2002;115(Pt 11):2389-97.

7. Ghetie V, Hubbard JG, Kim JK, Tsen MF, Lee Y, Ward ES. Abnormally short serum half-lives of IgG in beta 2-microglobulin-deficient mice. Eur J Immunol. 1996;26(3):690-6. https://doi. org/10.1002/eji.1830260327.

8. Israel EJ, Wilsker DF, Hayes KC, Schoenfeld D, Simister NE. Increased clearance of IgG in mice that lack beta 2-microglobulin: possible protective role of FcRn. Immunology. 1996;89(4):573-8. https://doi.org/10.1046/j.1365-2567.1996.d01-775.x.

9. Shields RL, Namenuk AK, Hong K, Meng YG, Rae J, Briggs J, et al. High resolution mapping of the binding site on human IgG1 for Fc gamma RI, Fc gamma RII, Fc gamma RIII, and FcRn and design of $\mathrm{IgG} 1$ variants with improved binding to the Fc gamma R. J Biol Chem. 2001;276(9):6591-604. https://doi.org/10.1074/ jbc.M009483200.

10. Santagostino E, Martinowitz U, Lissitchkov T, Pan-Petesch B, Hanabusa H, Oldenburg J, et al. Long-acting recombinant coagulation factor IX albumin fusion protein (rIX-FP) in hemophilia B: results of a phase 3 trial. Blood. 2016;127(14):1761-9. https://doi. org/10.1182/blood-2015-09-669234.

11. Medesan C, Matesoi D, Radu C, Ghetie V, Ward ES. Delineation of the amino acid residues involved in transcytosis and catabolism of mouse IgG1. J Immunol. 1997;158(5):2211-7.

12. Hansen AL, Kay LE. Measurement of histidine $\mathrm{pKa}$ values and tautomer populations in invisible protein states. Proc Natl Acad Sci USA. 2014;111(17):E1705-12. https://doi.org/10.1073/ pnas. 1400577111.

13. Rath T, Baker K, Dumont JA, Peters RT, Jiang H, Qiao SW, et al. Fc-fusion proteins and FcRn: structural insights for longer-lasting and more effective therapeutics. Crit Rev Biotechnol. 2015;35(2):235-54. https://doi.org/10.3109/07388 551.2013 .834293$.

14. Gao X, Ji JA, Veeravalli K, Wang YJ, Zhang T, Mcgreevy W, et al. Effect of individual Fc methionine oxidation on FcRn binding: Met252 oxidation impairs FcRn binding more profoundly than Met428 oxidation. J Pharm Sci. 2015;104(2):368-77. https://doi. org/10.1002/jps.24136.

15. Liu D, Ren D, Huang H, Dankberg J, Rosenfeld R, Cocco MJ, et al. Structure and stability changes of human IgG1 Fc as a consequence of methionine oxidation. Biochemistry. 2008;47(18):5088-100. https://doi.org/10.1021/bi702238b.

16. Bertolotti-Ciarlet A, Wang W, Lownes R, Pristatsky P, Fang Y, McKelvey $\mathrm{T}$, et al. Impact of methionine oxidation on the binding of human IgG1 to Fc Rn and Fc gamma receptors. Mol Immunol. 2009;46(8-9):1878-82. https://doi.org/10.1016/j.molim m.2009.02.002.

17. Liu L. Pharmacokinetics of monoclonal antibodies and Fc-fusion proteins. Protein Cell. 2018;9(1):15-32. https://doi.org/10.1007/ s13238-017-0408-4.

18. Czajkowsky DM, Hu J, Shao Z, Pleass RJ. Fc-fusion proteins: new developments and future perspectives. EMBO Mol Med. 2012;4(10):1015-28. https://doi.org/10.1002/emmm.201201379.

19. Mancuso ME, Santagostino E. Outcome of clinical trials with new extended half-life FVIII/IX concentrates. J Clin Med. 2017. https ://doi.org/10.3390/jem6040039.

20. Sleep D. Albumin and its application in drug delivery. Expert Opin Drug Deliv. 2015;12(5):793-812. https://doi.org/10.1517/17425 247.2015.993313.
21. Nilvebrant J, Hober S. The albumin-binding domain as a scaffold for protein engineering. Comput Struct Biotechnol J. 2013;6:e201303009. https://doi.org/10.5936/csbj.201303009.

22. Seijsing J, Sobieraj AM, Keller N, Shen Y, Zinkernagel AS, Loessner MJ, et al. Improved biodistribution and extended serum half-life of a bacteriophage endolysin by albumin binding domain fusion. Front Microbiol. 2018;9:2927. https://doi.org/10.3389/ fmicb.2018.02927.

23. Li R, Yang H, Jia D, Nie Q, Cai H, Fan Q, et al. Fusion to an albumin-binding domain with a high affinity for albumin extends the circulatory half-life and enhances the in vivo antitumor effects of human TRAIL. J Control Release. 2016;228:96-106. https:// doi.org/10.1016/j.jconrel.2016.03.004.

24. Holt LJ, Basran A, Jones K, Chorlton J, Jespers LS, Brewis $\mathrm{ND}$, et al. Anti-serum albumin domain antibodies for extending the half-lives of short lived drugs. Protein Eng Des Sel. 2008;21(5):283-8. https://doi.org/10.1093/protein/gzm067.

25. Davé E, Adams R, Zaccheo O, Carrington B, Compson JE, Dugdale $\mathrm{S}$, et al. Fab-dsFv: a bispecific antibody format with extended serum half-life through albumin binding. mAbs. 2016;8(7):131935. https://doi.org/10.1080/19420862.2016.1210747.

26. Jo M, Ko S, Hwang B, Min SW, Ha JY, Lee JC, et al. Engineered human Fc $\gamma$ RIIa fusion: a novel strategy to extend serum half-life of therapeutic proteins. Biotechnol Bioeng. 2020;117(8):2351-61. https://doi.org/10.1002/bit.27374.

27. Kulasekararaj AG, Hill A, Rottinghaus ST, Langemeijer S, Wells R, Gonzalez-Fernandez FA, et al. Ravulizumab (ALXN1210) vs eculizumab in C5-inhibitor-experienced adult patients with $\mathrm{PNH}$ : the 302 study. Blood. 2019;133(6):540-9. https://doi.org/10.1182/ blood-2018-09-876805.

28. Ko SY, Pegu A, Rudicell RS, Yang ZY, Joyce MG, Chen X, et al. Enhanced neonatal $\mathrm{Fc}$ receptor function improves protection against primate SHIV infection. Nature. 2014;514(7524):642-5. https://doi.org/10.1038/nature13612.

29. Gautam R, Nishimura Y, Gaughan N, Gazumyan A, Schoofs $\mathrm{T}$, Buckler-White A, et al. A single injection of crystallizable fragment domain-modified antibodies elicits durable protection from SHIV infection. Nat Med. 2018;24(5):610-6. https://doi. org/10.1038/s41591-018-0001-2.

30. Zalevsky J, Chamberlain AK, Horton HM, Karki S, Leung IW, Sproule TJ, et al. Enhanced antibody half-life improves in vivo activity. Nat Biotechnol. 2010;28(2):157-9. https://doi. org/10.1038/nbt.1601.

31. Kim JK, Firan M, Radu CG, Kim CH, Ghetie V, Ward ES. Mapping the site on human IgG for binding of the MHC class I-related receptor FcRn. Eur J Immunol. 1999;29(9):2819-25. https://doi. org/10.1002/(sici)1521-4141(199909)29:09\%3c2819::Aid-immu2 819\%3e3.0.Co;2-6.

32. Martin WL, West AP Jr, Gan L, Bjorkman PJ. Crystal structure at $2.8 \AA$ of an FcRn/heterodimeric Fc complex: mechanism of pH-dependent binding. Mol Cell. 2001;7(4):867-77. https://doi. org/10.1016/s1097-2765(01)00230-1.

33. Saunders KO, Pegu A, Georgiev IS, Zeng M, Joyce MG, Yang ZY, et al. Sustained delivery of a broadly neutralizing antibody in nonhuman primates confers long-term protection against simian/human immunodeficiency virus infection. J Virol. 2015;89(11):5895-903. https://doi.org/10.1128/jvi.00210-15.

34. Borghi S, Bournazos S, Thulin NK, Li C, Gajewski A, Sherwood $\mathrm{RW}$, et al. FcRn, but not Fc $\gamma$ Rs, drives maternal-fetal transplacental transport of human IgG antibodies. Proc Natl Acad Sci USA. 2020;117(23):12943-51. https://doi.org/10.1073/pnas.20043 25117.

35. Jennewein MF, Goldfarb I, Dolatshahi S, Cosgrove C, Noelette FJ, Krykbaeva M, et al. Fc glycan-mediated regulation of placental antibody transfer. Cell. 2019;178(1):202-15.e14. https://doi. org/10.1016/j.cell.2019.05.044. 
36. Dall'Acqua WF, Woods RM, Ward ES, Palaszynski SR, Patel $\mathrm{NK}$, Brewah YA, et al. Increasing the affinity of a human IgG1 for the neonatal Fc receptor: biological consequences. J Immunol. 2002;169(9):5171-80. https://doi.org/10.4049/jimmu nol.169.9.5171.

37. Dall'Acqua WF, Kiener PA, Wu H. Properties of human IgG1s engineered for enhanced binding to the neonatal Fc receptor (FcRn). J Biol Chem. 2006;281(33):23514-24. https://doi. org/10.1074/jbc.M604292200.

38. Oganesyan V, Damschroder MM, Cook KE, Li Q, Gao C, Wu $\mathrm{H}$, et al. Structural insights into neonatal Fc receptor-based recycling mechanisms. J Biol Chem. 2014;289(11):7812-24. https:// doi.org/10.1074/jbc.M113.537563.

39. Yeung YA, Leabman MK, Marvin JS, Qiu J, Adams CW, Lien $\mathrm{S}$, et al. Engineering human IgG1 affinity to human neonatal Fc receptor: impact of affinity improvement on pharmacokinetics in primates. J Immunol. 2009;182(12):7663-71. https://doi. org/10.4049/jimmunol.0804182.

40. Mackness BC, Jaworski JA, Boudanova E, Park A, Valente D, Mauriac $\mathrm{C}$, et al. Antibody $\mathrm{Fc}$ engineering for enhanced neonatal $\mathrm{Fc}$ receptor binding and prolonged circulation half-life. mAbs. 2019;11(7):1276-88. https://doi.org/10.1080/19420 862.2019.1633883.

41. Booth BJ, Ramakrishnan B, Narayan K, Wollacott AM, Babcock GJ, Shriver Z, et al. Extending human IgG half-life using structure-guided design. mAbs. 2018;10(7):1098-110. https://doi. org/10.1080/19420862.2018.1490119.

42. Jung ST, Kelton W, Kang TH, Ng DT, Andersen JT, Sandlie I, et al. Effective phagocytosis of low Her 2 tumor cell lines with engineered, aglycosylated IgG displaying high Fc $\gamma$ RIIa affinity and selectivity. ACS Chem Biol. 2013;8(2):368-75. https://doi. org/10.1021/cb300455f.

43. Lee CH, Kang TH, Godon O, Watanabe M, Delidakis G, Gillis $\mathrm{CM}$, et al. An engineered human Fc domain that behaves like a $\mathrm{pH}$-toggle switch for ultra-long circulation persistence. Nat Commun. 2019;10(1):5031. https://doi.org/10.1038/s41467-019-13108 -2 .

44. Abdiche YN, Yeung YA, Chaparro-Riggers J, Barman I, Strop $\mathrm{P}$, Chin SM, et al. The neonatal Fc receptor ( $\mathrm{FcRn})$ binds independently to both sites of the $\mathrm{IgG}$ homodimer with identical affinity. mAbs. 2015;7(2):331-43. https://doi.org/10.1080/19420 862.2015.1008353.

45. Souders CA, Nelson SC, Wang Y, Crowley AR, Klempner MS, Thomas W Jr. A novel in vitro assay to predict neonatal Fc receptor-mediated human IgG half-life. mAbs. 2015;7(5):912-21. https ://doi.org/10.1080/19420862.2015.1054585.

46. Grevys A, Nilsen J, Sand KMK, Daba MB, Øynebråten I, Bern M, et al. A human endothelial cell-based recycling assay for screening of FcRn targeted molecules. Nat Commun. 2018;9(1):621. https ://doi.org/10.1038/s41467-018-03061-x.

47. Tabrizi M, Neupane D, Elie SE, Shankaran H, Juan V, Zhang S, et al. Pharmacokinetic properties of humanized IgG1 and IgG4 antibodies in preclinical species: translational evaluation. AAPS J. 2019;21(3):39. https://doi.org/10.1208/s12248-019-0304-3.

48. Latvala S, Jacobsen B, Otteneder MB, Herrmann A, Kronenberg S. Distribution of FcRn across species and tissues. J Histochem Cytochem. 2017;65(6):321-33. https://doi.org/10.1369/00221 55417705095

49. Deng R, Iyer S, Theil FP, Mortensen DL, Fielder PJ, Prabhu $S$. Projecting human pharmacokinetics of therapeutic antibodies from nonclinical data: what have we learned? mAbs. 2011;3(1):61-6. https://doi.org/10.4161/mabs.3.1.13799.

50. Dong JQ, Salinger DH, Endres CJ, Gibbs JP, Hsu CP, Stouch BJ, et al. Quantitative prediction of human pharmacokinetics for monoclonal antibodies: retrospective analysis of monkey as a single species for first-in-human prediction. Clin Pharmacokinet.
2011;50(2):131-42. https://doi.org/10.2165/11537430-00000 0000-00000.

51. Oitate M, Masubuchi N, Ito T, Yabe Y, Karibe T, Aoki T, et al. Prediction of human pharmacokinetics of therapeutic monoclonal antibodies from simple allometry of monkey data. Drug Metab Pharmacokinet. 2011;26(4):423-30. https://doi.org/10.2133/ dmpk.dmpk-11-rg-011.

52. Burvenich IJ, Farrugia W, Lee FT, Catimel B, Liu Z, Makris D, et al. Cross-species analysis of Fc engineered anti-Lewis-Y human IgG1 variants in human neonatal receptor transgenic mice reveal importance of S254 and Y436 in binding human neonatal $\mathrm{Fc}$ receptor. mAbs. 2016;8(4):775-86. https://doi.org/10.1080/19420 862.2016.1156285.

53. Proetzel G, Roopenian DC. Humanized FcRn mouse models for evaluating pharmacokinetics of human $\mathrm{IgG}$ antibodies. Methods. 2014;65(1):148-53. https://doi.org/10.1016/j.ymeth.2013.07.005.

54. Nilsen J, Sandlie I, Roopenian DC, Andersen JT. Animal models for evaluation of albumin-based therapeutics. Curr Opin Chem Eng. 2018;19:68-76. https://doi.org/10.1016/j.coche.2017.11.007.

55. Petkova SB, Akilesh S, Sproule TJ, Christianson GJ, Al Khabbaz $\mathrm{H}$, Brown AC, et al. Enhanced half-life of genetically engineered human IgG1 antibodies in a humanized FcRn mouse model: potential application in humorally mediated autoimmune disease. Int Immunol. 2006;18(12):1759-69. https://doi.org/10.1093/intim $\mathrm{m} / \mathrm{dx} 1110$.

56. Avery LB, Wang M, Kavosi MS, Joyce A, Kurz JC, Fan YY, et al. Utility of a human FcRn transgenic mouse model in drug discovery for early assessment and prediction of human pharmacokinetics of monoclonal antibodies. mAbs. 2016;8(6):1064-78. https://doi.org/10.1080/19420862.2016.1193660.

57. Finch DK, Sleeman MA, Moisan J, Ferraro F, Botterell S, Campbell J, et al. Whole-molecule antibody engineering: generation of a high-affinity anti-IL-6 antibody with extended pharmacokinetics. J Mol Biol. 2011;411(4):791-807. https://doi.org/10.1016/j. jmb.2011.06.031.

58. National Cancer Institute. Anti-PD1/CTLA4 bispecific antibody XmAb20717. NCI Drug Dictionary. https://www.cancer.gov/ publications/dictionaries/cancer-drug/def/793410. Accessed 22 Sep 2020.

59. National Cancer Institute. Anti-PD1/ICOS bispecific monoclonal antibody XmAb23104. NCI Drug Dictionary. https://www.cance r.gov/publications/dictionaries/cancer-drug/def/796973. Accessed 22 Sep 2020.

60. National Cancer Institute. Anti-CTLA-4/LAG-3 bispecific antibody XmAb22841. NCI Drug Dictionary. https://www.cance r.gov/publications/dictionaries/cancer-drug/def/797814. Accessed 22 Sep 2020.

61. Pinto D, Park Y-J, Beltramello M, Walls AC, Tortorici MA, Bianchi S, et al. Cross-neutralization of SARS-CoV-2 by a human monoclonal SARS-CoV antibody. Nature. 2020;583(7815):290-5. https://doi.org/10.1038/s41586-020-2349-y.

62. Grobben M, Stuart RAL, van Gils MJ. The potential of engineered antibodies for HIV-1 therapy and cure. Curr Opin Virol. 2019;38:70-80. https://doi.org/10.1016/j.coviro.2019.07.007.

63. Li Y, O'Dell S, Walker LM, Wu X, Guenaga J, Feng Y, et al. Mechanism of neutralization by the broadly neutralizing HIV-1 monoclonal antibody VRC01. J Virol. 2011;85(17):8954-67. https ://doi.org/10.1128/JVI.00754-11.

64. Gaudinski MR, Coates EE, Houser KV, Chen GL, Yamshchikov G, Saunders JG, et al. Safety and pharmacokinetics of the Fc-modified HIV-1 human monoclonal antibody VRC01LS: a phase 1 open-label clinical trial in healthy adults. PLoS Med. 2018;15(1):e1002493. https://doi.org/10.1371/journ al.pmed.1002493.

65. Julien J-P, Sok D, Khayat R, Lee JH, Doores KJ, Walker LM, et al. Broadly neutralizing antibody PGT121 allosterically modulates 
CD4 binding via recognition of the HIV-1 gp120 V3 base and multiple surrounding glycans. PLoS Pathog. 2013;9(5):e1003342. https://doi.org/10.1371/journal.ppat.1003342.

66. Mouquet H, Scharf L, Euler Z, Liu Y, Eden C, Scheid JF, et al. Complex-type $N$-glycan recognition by potent broadly neutralizing HIV antibodies. Proc Natl Acad Sci USA. 2012;109(47):E326877. https://doi.org/10.1073/pnas.1217207109.

67. Lazar GA, Dang W, Karki S, Vafa O, Peng JS, Hyun L, et al. Engineered antibody $\mathrm{Fc}$ variants with enhanced effector function. Proc Natl Acad Sci USA. 2006;103(11):4005-10. https:// doi.org/10.1073/pnas.0508123103.

68. Richards JO, Karki S, Lazar GA, Chen H, Dang W, Desjarlais JR. Optimization of antibody binding to Fc $\gamma$ RIIa enhances macrophage phagocytosis of tumor cells. Mol Cancer Ther. 2008;7(8):2517-27. https://doi.org/10.1158/1535-7163. mct-08-0201.

69. Gilman MSA, Furmanova-Hollenstein P, Pascual G, van't Wout AB, Langedijk JPM, McLellan JS. Transient opening of trimeric prefusion RSV F proteins. Nat Commun. 2019;10(1):205. https ://doi.org/10.1038/s41467-019-09807-5.

70. Griffin MP, Yuan Y, Takas T, Domachowske JB, Madhi SA, Manzoni P, et al. Single-dose nirsevimab for prevention of RSV in preterm infants. N Engl J Med. 2020;383(5):415-25. https://doi. org/10.1056/NEJMoa1913556.

71. Domachowske JB, Khan AA, Esser MT, Jensen K, Takas T, Villafana T, et al. Safety, tolerability and pharmacokinetics of MEDI8897, an extended half-life single-dose respiratory syncytial virus prefusion F-targeting monoclonal antibody administered as a single dose to healthy preterm infants. Pediatr Infect Dis J. 2018;37(9):886-92. https://doi.org/10.1097/inf.000000000000191 6.

72. Borrok MJ, Wu Y, Beyaz N, Yu XQ, Oganesyan V, Dall'Acqua $\mathrm{WF}$, et al. $\mathrm{pH}$-dependent binding engineering reveals an FcRn affinity threshold that governs IgG recycling. J Biol Chem. 2015;290(7):4282-90. https://doi.org/10.1074/jbc.M114.603712.

73. Zheng Y, Tesar DB, Benincosa L, Birnböck H, Boswell CA, Bumbaca D, et al. Minipig as a potential translatable model for monoclonal antibody pharmacokinetics after intravenous and subcutaneous administration. mAbs. 2012;4(2):243-55. https://doi. org/10.4161/mabs.4.2.19387.

74. Li B, Tesar D, Boswell CA, Cahaya HS, Wong A, Zhang J, et al. Framework selection can influence pharmacokinetics of a humanized therapeutic antibody through differences in molecule charge. mAbs. 2014;6(5):1255-64. https://doi.org/10.4161/mabs.29809.

75. Kelly RL, Yu Y, Sun T, Caffry I, Lynaugh H, Brown M, et al. Target-independent variable region mediated effects on antibody clearance can be FcRn independent. mAbs. 2016;8(7):1269-75. https://doi.org/10.1080/19420862.2016.1208330.

76. Nathan D, Thomsen MB, Pace CS, Zhang X, Hung M, Nagel MR, Carr BA, Hu E, Yu H, Stepan G, Goldsmith J, Xia B, Jin D, Corbin JA, Geleziunas R. GS-9722: first-in-class, effector-enhanced, broadly neutralizing antibody for HIV cure. In: Conference on retroviruses and opportunistic infections. 2019. https://www.croic onference.org/abstract/gs-9722-first-class-effector-enhancedbroadly-neutralizing-antibody-hiv-cure/. Accessed 5 Oct 2020.

77. Ruane EDP, Workowski K, Begley R, Humeniuk R, Makadzange T, West SK, Liu H, Li Y, Ling J, Stamm LM, German P, Eron JJ, Kumar PN, DeJesus E. Safety and pharmacokinetics of GS-9722 in HIV-negative participants and people with HIV. In: Conference on retroviruses and opportunistic infections. 2020. https:// www.croiconference.org/abstract/safety-pharmacokinetics-of-gs9722-in-hiv-negative-participants-and-people-with-hiv/. Accessed 5 Oct 2020 